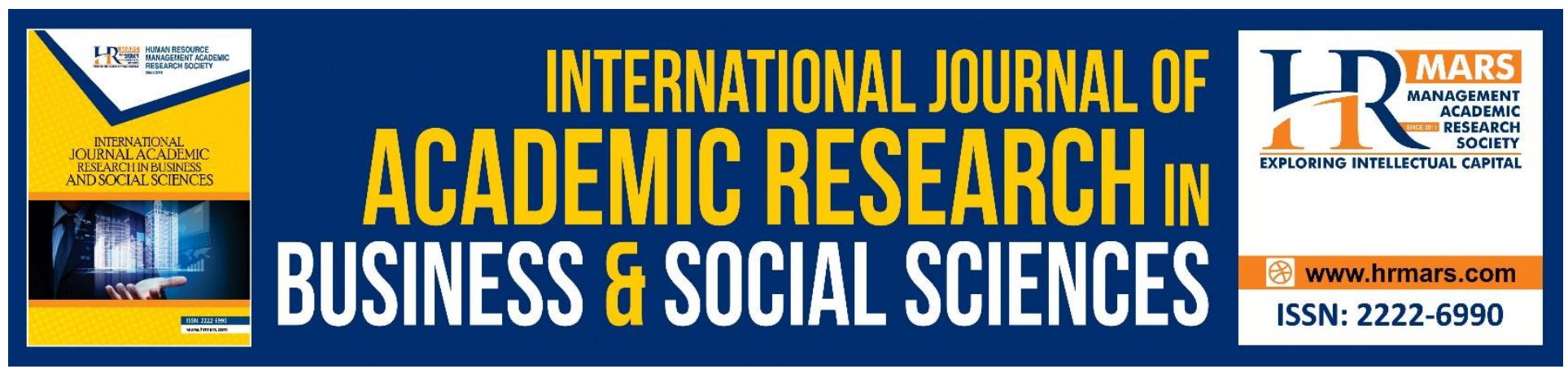

\title{
Malaysia-China Intra Industry Trade
}

\author{
Hartini M. and Norailis A.W.
}

To Link this Article: http://dx.doi.org/10.6007/IJARBSS/v8-i9/4660

DOI: $\quad 10.6007 /$ IJARBSS/v8-i9/4660

Received: 04 August 2018, Revised: 27 August 2018, Accepted: 29 Sept 2018

Published Online: 15 October 2018

In-Text Citation: (Hartini \& Norailis, 2018)

To Cite this Article: Hartini, M., \& Norailis, A. W. (2018). Malaysia-China Intra Industry Trade. International Journal of Academic Research in Business and Social Sciences, 8(9), 863-869.

\section{Copyright: (c) 2018 The Author(s)}

Published by Human Resource Management Academic Research Society (www.hrmars.com)

This article is published under the Creative Commons Attribution (CC BY 4.0) license. Anyone may reproduce, distribute, translate and create derivative works of this article (for both commercial and non-commercial purposes), subject to full attribution to the original publication and authors. The full terms of this license may be seen at: http://creativecommons.org/licences/by/4.0/legalcode

Vol. 8, No. 9, September 2018, Pg. 863 - 869

Full Terms \& Conditions of access and use can be found at http://hrmars.com/index.php/pages/detail/publication-ethics 


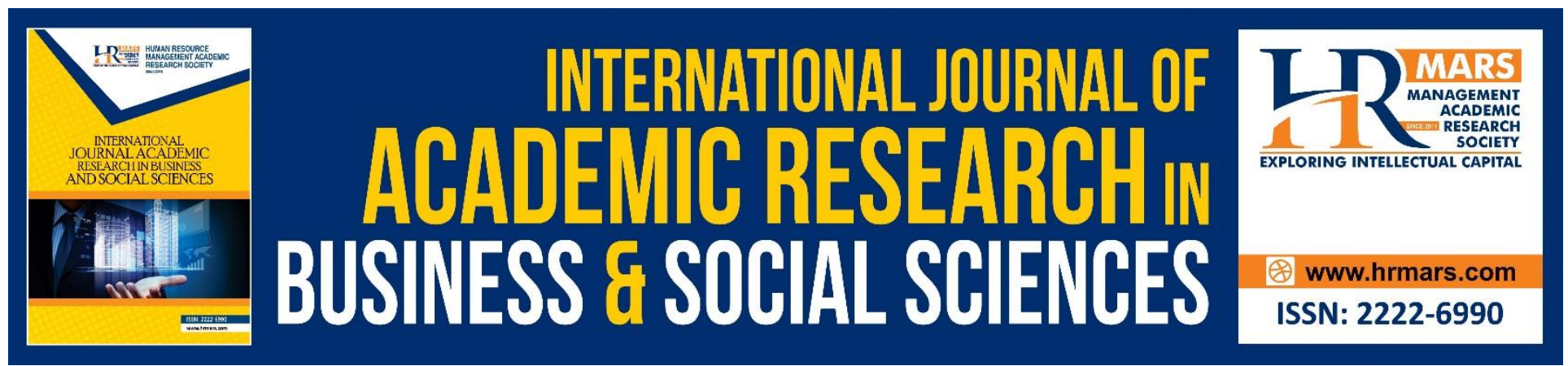

\title{
Malaysia-China Intra Industry Trade
}

\author{
Hartini M. and Norailis A.W. \\ Fakulti Ekonomi dan Muamalat, Universiti Sains Islam Malaysia, 71800 Nilai, Negeri Sembilan, \\ Malaysia.
}

\begin{abstract}
In this paper we investigate the index of intra industry trade between Malaysia and China. Our findings indicate that intra industry trade in manufactured goods between both countries is very significant which represent more than 60 percent of the total trade volume. Another analysis has been conducted to examine the share of intra industry trade by orientation. The findings show mixed results between export and domestic oriented products analyzed.
\end{abstract}

Keywords: Malaysia, China, Intra Industry Trade

Malaysian economy has always been trade dependent, influenced by both its major trading partners and by commodity prices. The rising share of manufactures in the total exports of Malaysia for more than three decades is perceive to be a result of the growing volume of intra industry trade flows.

Malaysia's relationship with China dated back as far as from the Ming Dynasty alliance with the Malacca Sultanate. However, the nature and structure of the relationship have evolve significantly since then. The foreign relations between Malaysia and China have positively changed after the end of World War II with the political and cultural connections between the both countries began to strengthen. Malaysia's trade ties with China have grown faster than those with the rest of the world, particularly since the financial crisis in 1997-98 (Kwek and Tham. 2005).

It was since 2005 when Malaysia had maintained an increasing and continuous trade with the Republic of China (Niam, 2015; Kwek and Tham, 2005). The total bilateral trade volume between Malaysia and China in 2005 reached US\$30.71 billion, an increase of approximately 16.9 percent from 2004 trade. China main exports consists of products such as cereal, machinery and electronic products, textile, clothing and accessories, steel, crude oil, footwear, and vegetables. China's import from Malaysia was US\$20.1 billion, an increase of approximately 10.6 percent from 2004 . The major imported products include machinery and electronic products, palm oil, plastics, natural rubber, unprocessed wood, product oil, steel, and crude oil. 
According to the Malaysia External Trade Development Corporation (MATRADE) business news released on 16 December 2016, total bilateral trade volume for a duration from January to October for that particular year reached US\$43.08 billion, an increase of approximately 1.2 percent from 2015 trade. Main contribution came from electrical and electronics products (42.7 percent), followed by chemicals and chemical products (10.4 percent), petroleum products (10.2 percent), palm oil and palm-based products ( 6 percent) and manufactures of metal ( 4.5 percent).

Intra industry trade is generally classified as a simultaneous export and import of similar types of goods or services belonging to the same industry, thus representing the exchange of these products 'within' rather than 'between' industries. Intra-industry trade particularly related to trade in merchandised goods has been recognized as a channel for economic growth.

The phenomenon of intra-industry trade first received attention in the 1960s in studies by Verdoorn (1960) and Balassa (1966) when the European Economic Community (EEC) faced problem to settle disputes between member countries, to gradually eliminate tax barriers and tariffs within and between the member countries and to equalize the tariffs and taxes on imports for all member countries. However, at a later extend, following the EEC remarkable trading development the earlier concepts were properly developed and was later known as intra industry trade.

First attempt to measure the share of intra-industry trade index between Malaysia and its traditional trading partners was by Ariff (1991). In this study the author had estimated the indexes using the Grubel and Lloyd index for period from 1970 to 1987. His analysis indicate that there is a significant increase in Malaysia's intra-industry trade with all its traditional trading partners such as the United States, Japan, Canada, Australia, New Zealand, NIEs and ASEAN. The trade with the US, the Northeast Asian NIEs, and the ASEAN partners was particularly significant with intra-industry trade indexes increased from 3.8 percent to 64.8 percent, 12.5 percent to 43.1 percent and 45.8 percent to 70.0 percent from 1970 to 1987, respectively. The growing importance of intra-industry trade from 1970 to 1987 was attributable largely to the activities of Multinational Corporations (MNCs). His study also indicated that the bulk of intra-industry trade consisted of intra-firm sales. The MNCs operating in Malaysia had generated both exports and imports through their international investment and trading networks. For example, the United States and Japanese firms in the electronics industry have developed complex production networks that span several countries in the Asia-Pacific region.

In another study, Arip et. al. (2011) examine the bilateral trade pattern between Japan, Malaysia and China (JMC) using the intra-industry trade (IIT) index analysis from 1980 to 2005. Their study found that China's fast-growing industrialization has resulted in the expansion of trade in horizontally differentiated products between Malaysia and China. The index of horizontal intra industry trade shows an upward trend from medium index of intra industry trade $(0.333<1 \mathrm{IT}<0.666)$ to higher index of intra industry trade (IIT $\geq 0.666)$. More impressively, Malaysia-China's higher composition of horizontal intra industry trade has expanded without significant changes in vertical 
INTERNATIONAL JOURNAL OF ACADEMIC RESEARCH IN BUSINESS AND SOCIAL SCIENCES

Vol. 8, No. 9, Sept. 2018, E-ISSN: 2222-6990 (C) 2018 HRMARS

intra industry trade. This implies that both countries especially China has rapidly improved its capacity in production activities that are not only of higher added value but also of higher quality.

\section{Problem Statement}

Malaysia's intra industry trade with China particularly in manufactured goods is assume to be one of the channels that contribute to trade growth between both countries. The Malaysian economy has always been trade dependent, and the rising share of manufactures in the total exports of Malaysia for more than three decades was considered a result of the growing volume of intra industry trade flows. With the changing trade direction since 2000s, our study perceive that it is important to analyze the share and extend of intra-industry trade which re-shape the trade trend between Malaysia and China.

\section{The Aim of Research}

This paper conducted research to analyze the intra-industry trade of aggregate manufactured goods at Standard Industrial Trade Classification (SITC) 3-digit level. For a detail analysis we have calculated the index for products classified as export and domestic oriented industries. The exportoriented industries are rubber products, electrical and electronic products, petroleum and fuel products, machinery and equipment and professional and scientific instruments industries. Meanwhile the domestic oriented industries include paper and paper products, chemical and chemical products, transport equipment, metal and metal product and textiles and apparel products.

\section{Method of Research}

Following the formula proposed by Grubel and Lloyd (1975) the index for intra-industry trade is calculated as:

IITij = [ $1-\Sigma|X i j-M i j| ~ / \Sigma(X i j+M i j)]$

where the subscript $i$ denotes industry and the subscript $j$ denotes country; $X$ denotes exports and $M$ denotes imports of the related industry and country, respectively. The computed value of IITij lies between 0 and 1 . The closer the value of the index to 1 the greater is the degree of intra- industry trade. In other words, if Xij=Mij, then IITij would equal 1 indicating that all trade in industry $i$ for country $j$ is intra-industry and when either $X i j=0$ or $M i j=0$ then the value of IITij would equal 0 indicating that all trade in industry $i$ for country $j$ is inter-industry trade. Trade data between Malaysia and China are obtain from the United Nations Conference on Trade and Development (UNCTAD) database.

\section{Analysis and Discussion}

Our study has calculated the intra industry trade indexes for aggregate manufactured goods classified at SITC 5 to SITC 8 (less SITC 667 and 68) between Malaysia and some selected countries including China. The period analyzed is from 1995 to 2016 and findings are as presented in Appendix 1. 
Figure in Appendix 1 shows that a significant intra industry trade between Malaysia and China exist during the period analyzed. However the indexes indicate that it is in a decreasing pattern. In 1995 the index of intra industry trade was approximately 94 percent of the total trade which indicate a very significant flow of intra industry trade for the manufactured goods between Malaysia and China. However, the trade flow decrease to 67 percent in 2000. One of the factor that might contribute to such decrease are related to the 1996-1997 Asian Financial Crisis. With remarkable recovery plans and action proposed by the government to recover the economy, the index has increased from 67 percent in 2000 to highest 98 percent in 2010.

The indexes calculated also show that in 2011 the percentage has decline slightly to approximately 94 percent. This phenomenon was perceive to be related to the impact of global economics crisis started in 2007. The indexes trend had continue to decrease in 5 consecutive years until registered at 72 percent in 2015. This findings might indicate that the flow of intra industry trade products between Malaysia and China has decrease approximately 23 percent during these years.

Further analysis of the trade index by products orientation is presented in Appendix 2. Intra industry trade indexes calculated for export oriented industries shows mixed result of an increase and decrease of trade throughout the period analyzed. Similar to the report by the Malaysia External Trade Development Corporation (MATRADE), the most significant contribution of intra industry trade in export oriented products is made by electrical and electronic products. In 1995 this sub-industries products represent approximately 99 percent intra industry trade as a share of total trade. Although the index decrease to 70 percent in 2005, the trend has recovered to registered at 97 percent in 2015. The electronics products lead the electrical and electronics industry whereby more than 38 per cent of the trade is contributed by semiconductor devices, integrated circuits (ICs), transistors and valves. Meanwhile the electrical products consists of household appliances, electrical fittings, wires \& cables and automotive batteries. The MNCs has continue to be the main catalyst in the development of this sector.

Next contribution of export oriented industry is reflected in optical and scientific instruments products intra industry trade. In 1995 the intra industry trade share consisted of 86 percent of the total trade. Similar to the trend show by aggregate manufactured goods, intra industry trade of the products have recorded decreses in the last five years during period analyzed. The indexes recorded approximately 82 percent in 2015. Another significant export oriented industries between Malaysia and China is machinery and equipments products. Intra industry trade index for this products recorded approximately 70 percent. share of total trade share in 1995. In 2015, the trade share has increased to 82 percent.

Last two components analyzed in the export oriented categories is the petroleum and fuel products and the rubber products. The analysis indicates a very significant increase in intra-industry trade share for both products. The findings show that in 1995 rubber products recorded 44 percent of intra industry trade share. Meanwhile petroleum and fuels products recorded only 20 percent of the trade share. Since then, the intra industry trade share has recorded a continuous increasing trend 
INTERNATIONAL JOURNAL OF ACADEMIC RESEARCH IN BUSINESS AND SOCIAL SCIENCES Vol. 8, No. 9, Sept. 2018, E-ISSN: 2222-6990 (C) 2018 HRMARS

whereby both sub-industries have recorded a trade share of 90 percent and 84 percent intra industry trade share, respectively in 2015.

From the domestic oriented industries classification, our analysis show that the highest intra industry trade share exist in the chemical and chemical product industries with share of more than 60 percent of the total trade in 1995. This products categoriees has recorded an increase to 98 percent in 2015. Transport and equipments recorded a static movement of the trade share with an average of 76 percent, meanwhile the rest of the domestic oriented sub-industries such as paper and paper productas, metal and metal products and textiles and clothing apparels recorded a dramatically decreasing trend of intra industry trade share during the period studied.

\section{Conclusion}

Our research indicates that there is a significant flow of intra-industry trade since 1995 until 2015 between Malaysia and China. The analysis of aggregate manufactured goods show that there exist a very significant flow of intra industry trade for the manufactured goods between Malaysia and China. Meanwhile analysis on detailed export and domestic oriented products have shown mixed results. Some of the industries experienced robust increased in the share of intra industry trade throughout the period studied, whereas the other industries indicate a decreasing pattern.

\section{References}

Ariff, M. (1991), 'The Malaysian Economy: Pacific Connections', Oxford University Press, Kuala Lumpur.

Ariff, M., Hill H. (1985), Export-Oriented Industrialisation: The ASEAN Experience, The Journal of Asian Studies, XV, 410 - 437.

Balassa, B. (1966), Tariff Reductions and Trade in Manufactures among the Industrial Countries, American Economic Review, 56, 466 - 473.

Grubel, H.G., Lloyd, P.J. (1975), 'Intra-industry Trade: The Theory and Measurement of International Trade in Differentiated Products', New York:John Wiley and Sons.

Kuik, C. C. (2008), "The Essence of Hedging: Malaysia and Singapore's Response to a Rising China," Contemporary Southeast Asia: A Journal of International and Strategic Affairs, 30(2), 159 -185.

Kwek, K.T., Tham S.Y. (2005), Malaysia-China Trade: Growth, Opportunities And Challenges, Kuala Lumpur: ICS Working Paper No, 2005-2.

Niam, S. W. (2015), "Malaysia Remains China's Top Trading Partner in ASEAN," Avaialable at http://web10.bernama.com/asean2015/newsdetail.php?id=1100373

Oh, E. S., David H. (2016), Malaysia's Relations with the Major Powers:China and the United States. Available at https://www.rsis.edu.sg/wp-content/uploads/2016/03/Malaysia-Update-March2016 Copy Finalised.pdf

Verdoorn, P.J. (1960), 'The Intra Block Trade of Benelux', in E.A.G Robinson (eds.), 'Euro Consequences of the Size of Nations', London. 
INTERNATIONAL JOURNAL OF ACADEMIC RESEARCH IN BUSINESS AND SOCIAL SCIENCES Vol. 8, No. 9, Sept. 2018, E-ISSN: 2222-6990 @ 2018 HRMARS

\begin{tabular}{l|ccccccccc}
\hline Country & $\begin{array}{c}\mathbf{1 9 9 5} \\
\mathbf{( \% )}\end{array}$ & $\begin{array}{c}\mathbf{2 0 0 0} \\
\mathbf{( \% )}\end{array}$ & $\begin{array}{c}\mathbf{2 0 0 5} \\
\mathbf{( \% )}\end{array}$ & $\begin{array}{c}\mathbf{2 0 1 0} \\
\mathbf{( \% )}\end{array}$ & $\begin{array}{c}\mathbf{2 0 1 1} \\
\mathbf{( \% )}\end{array}$ & $\begin{array}{c}\mathbf{2 0 1 2} \\
\mathbf{( \% )}\end{array}$ & $\begin{array}{c}\mathbf{2 0 1 3} \\
\mathbf{( \% )}\end{array}$ & $\begin{array}{c}\mathbf{2 0 1 4} \\
\mathbf{( \% )}\end{array}$ & $\begin{array}{c}\mathbf{2 0 1 5} \\
\mathbf{( \% )}\end{array}$ \\
\hline China & $\mathbf{9 4}$ & $\mathbf{6 7}$ & $\mathbf{7 2}$ & $\mathbf{9 8}$ & $\mathbf{9 4}$ & $\mathbf{8 5}$ & $\mathbf{8 0}$ & $\mathbf{7 7}$ & $\mathbf{7 2}$ \\
Indonesia & 71 & 74 & 76 & 96 & 81 & 74 & 80 & 78 & 81 \\
Japan & 50 & 86 & 85 & 69 & 74 & 71 & 76 & 79 & 84 \\
Singapore & 90 & 97 & 97 & 78 & 85 & 82 & 74 & 77 & 78 \\
Thailand & 74 & 91 & 91 & 99 & 99 & 99 & 96 & 97 & 98 \\
\hline
\end{tabular}

Source: Author's calculation based on UNCTAD database (1995-2015)

Appendix 1: Intra Industry Trade of Manufactured Goods with China and Selected ASEAN Countries

\begin{tabular}{|c|c|c|c|c|c|}
\hline Industries & $\begin{array}{c}1995 \\
(\%)\end{array}$ & $\begin{array}{c}2000 \\
(\%)\end{array}$ & $\begin{array}{c}2005 \\
(\%)\end{array}$ & $\begin{array}{c}2010 \\
(\%)\end{array}$ & $\begin{array}{r}2015 \\
(\%)\end{array}$ \\
\hline $\begin{array}{l}\text { Export Oriented: } \\
\text { Electrical and } \\
\text { Electronic Products }\end{array}$ & 99 & 98 & 70 & 81 & 97 \\
\hline Rubber Products & 44 & 31 & 66 & 84 & 90 \\
\hline $\begin{array}{l}\text { Petroleum and fuels } \\
\text { product }\end{array}$ & 20 & 33 & 55 & 73 & 84 \\
\hline $\begin{array}{l}\text { Machinery and } \\
\text { equipment }\end{array}$ & 70 & 88 & 65 & 96 & 82 \\
\hline $\begin{array}{l}\text { Optical and Scientific } \\
\text { instruments }\end{array}$ & 86 & 81 & 82 & 89 & 82 \\
\hline Domestic Oriented: & & & & & \\
\hline $\begin{array}{l}\text { Paper and paper } \\
\text { products }\end{array}$ & 13 & 34 & 48 & 20 & 7 \\
\hline $\begin{array}{l}\text { Chemical and } \\
\text { chemical products }\end{array}$ & 61 & 63 & 67 & 90 & 98 \\
\hline $\begin{array}{l}\text { Transport } \\
\text { equipment }\end{array}$ & 77 & 62 & 85 & 86 & 72 \\
\hline $\begin{array}{l}\text { Metal and metal } \\
\text { products }\end{array}$ & 36 & 66 & 55 & 21 & 21 \\
\hline $\begin{array}{l}\text { Textiles and Clothing } \\
\text { apparel }\end{array}$ & 30 & 51 & 43 & 52 & 28 \\
\hline
\end{tabular}

Source: Author's calculation based on UNCTAD database (1995-2015)

Appendix 2: Malaysia - China Intra Industry Trade for Selected Products by Orientation 